This article was downloaded by: [Carnegie Mellon University]

On: 14 October 2014, At: 23: 20

Publisher: Routledge

Informa Ltd Registered in England and Wales Registered Number: 1072954 Registered office: Mortimer House, 37-41 Mortimer Street, London W1T 3J H, UK

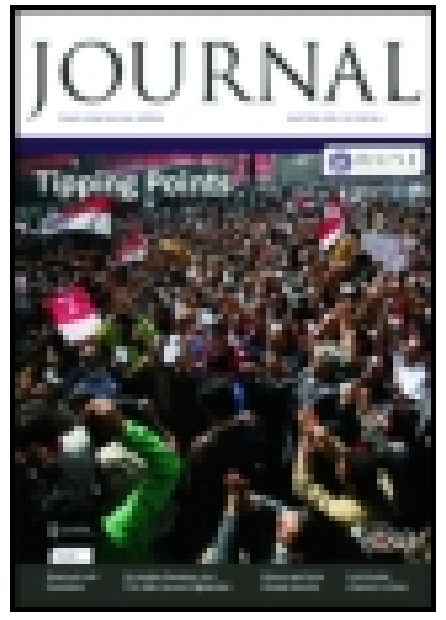

Royal United Services Institution. J ournal

Publication details, including instructions for authors and subscription information: http:// www. tandfonline.com/ loi/rusi 19

\title{
Electricity as Applied to Naval Purposes
}

Lieut. W. A. Chisholm-Batten R.N.

Published online: 11 Sep 2009.

To cite this article: Lieut. W. A. Chisholm-Batten R. N. (1885) Electricity as Applied to Naval Purposes, Royal United Services Institution. J ournal, 29:130, 721-743, DOI: 10.1080/03071848509424367

To link to this article: http://

dx. doi.org/ 10.1080/03071848509424367

\section{PLEASE SCROLL DOWN FOR ARTICLE}

Taylor \& Francis makes every effort to ensure the accuracy of all the information (the "Content") contained in the publications on our platform. However, Taylor \& Francis, our agents, and our licensors make no representations or 
warranties whatsoever as to the accuracy, completeness, or suitability for any purpose of the Content. Any opinions and views expressed in this publication are the opinions and views of the authors, and are not the views of or endorsed by Taylor \& Francis. The accuracy of the Content should not be relied upon and should be independently verified with primary sources of information. Taylor and Francis shall not be liable for any losses, actions, claims, proceedings, demands, costs, expenses, damages, and other liabilities whatsoever or howsoever caused arising directly or indirectly in connection with, in relation to or arising out of the use of the Content.

This article may be used for research, teaching, and private study purposes. Any substantial or systematic reproduction, redistribution, reselling, loan, sub-licensing, systematic supply, or distribution in any form to anyone is expressly forbidden. Terms \& Conditions of access and use can be found at http://www.tandfonline.com/page/terms-andconditions 
Friday, May 29, 1885.

aduiraz the Rigat HoN. Sir A. COOPER KEY, G.C.B., dic., \&c., Vice-President, in the Chair.

\title{
ELECTRICITY AS APPLIED TO NAVAL PURPOSES.
}

\author{
By Lient. W. A. Cusmoly-Batic., R.N. \\ I. Application for General Purposcs. \\ II. Application for War Purposes.
}

TuESE aro in somo cases mixed, and there is no sharply defined lino between them-take electric lighting as an instance. The ordinary internal lighting of a ship is quite distinct in itself from search-lighting, though produced by much tho samo means. They havo both grown independently; but in a ship of war, the great object should be to combine the two.

Electricity is a great power in skilled hands, and can bo used with safety and certainty even by slightly trained men, if only enough care and thought be taken in designing electrical appliances, to make their uso casy and abuse difficult.

'The applications of electricity on board ship are varions, and differ greatly. Sometimes it is necessary to use the electric forco in such a way that it has power to melt any metal, to produce an intenso light rivalling that of the sun, to propel a vessel, or to give serere nnd even fatal shocks to thoso handling its mechanism. At other times it is so gently applicd that although it acts through tho human body, it cunnot be felt by the most tender child; and at others, it is so exquisitely sensitive that it will carry faithfully the distinct tone of a certain voice, and indicate a change in its neighbourhood so slight as the movement by inclies of an ounce of lead.

The two properties of the electrio current which are generally made uso of are, first, that of causing heat when a comparatively great resistance is placed in the circuit; and, secondly, that of giving magnetic properties to any conductor through which it passes.

An apology is due for going into matters so simple, but in case there may be some who may not be familiar with these points, they will be briefly explained.

Electricity for naval parposes is produced by what may be termed a generator, which is geuerally eitler a machine deriving its power from the burning of coal, or a battery deriving its power from the slow burning of zinc.

The nest part of any 'electric appliance to be considered is tho circuit, that is to say, a condactor, generally metal, which allows tho 
current to circulate from the generator to the place of applica. and bach again. This is generally formed of copper or iron wire

The part of the conductor or lead which goes from the generate tho place of npplication may be called the main, and the part w. comes back may be called the retarn.

When the result desired is the developing of heat or light, a ? resistance, that is a small conductor, or one of a comparative b conducting snbstance, is introduced in the circuit at the des place.

For instance, if the electricity originally obtained by the bur of coal, and then carried in an accumulator, be allowed to pass main wire which must touch tho accumulator, to an incandescer glow-lamp and back by a retura wire, heat and light are produce the thread of carbon in tho lnmp, which has a.high resistance.

Or again, if the electricity produced by the burning of zinc batiery be allowed to pass through the main to a small wire and 1 agnin, sufficient licat is produced to fire a cliarge of gunpowder.

When the result required is an exertion of magnetic force, simplest, or at any rate the most familiar, form is the electric bell. a circait from a battery which slowly burns zinc, a current po round a coil of wirc, causing it to act as a magnet and to attra piece of iron which makes the clapper strike the bell.

Or again, if the current, orierinally obtaincd from the burnin coal, be alloricd to pass by the main to a magnetic arrangement back by the return, the resnlt is magnetic action which causes mol and is sufficient to drice a boat or any useful machine.

Thus much of the simple principles of electricity.

\section{Electric Lighting.}

The most important application of electricity for naral parpose perhaps, the lighting of ships.

Flectric lighting is almost entirely carricd out by an extensio the simple appliances which have been described. The current pe from the electric machine or generator nlong the main to the la and back by the retarn; that is to say, the illamination in a shi war is carried out by a large number of glow-lamps-usually al 300 - of about 20 candle-power, that is, 20 wax candles, 8 to the po: The elcctric machine is usually driven bs a steam-engine.

The adrantuges claimed for the use of clectric lighting on $b_{1}$ ship are many of them applicable, as jou nill notice, to its use shore.

1. It is cheaper than oil-at any rate than the oils allowed $t$ used on board men-of-war, and still more so than candles, which ] hitherto been the general illuminants.

2. There is far greater safety from fire, ns there is no occasion carrsing matches about or lighted candles, which in spite of I mules are often used naked. This is hardly surprising when ore h of the trouble which has to bo taken to aroid naked lights being? in mines; the use of electric lightiug also does away with that is bator of fires-the limp-room. 
3. It hardly heats tho air, and does not fonl it at all.

Many morchant steamers and somo ships in the Nary aro the lighted, the principal rcason against its cxtonded use in the latt being the fact that men-of-war pass much of their time witho getting up steam, but in troop-ships it has been almost universal introduced.

Andrews and Co., of Glasgow, haro just completed on board tl "Etruria" a largo installation which, in its proportions, surpass anything that has hitherto been attempted in the application of electr - light to stenm-ships. The "Ftrurin" carries about 850 liglits, and brief description will no doubt be interesting. Swan glow-lamps a used, and of these 90 are distributed in the enginc-room, stok holes, \&c. 103 lights altogether are used for lighting the ma dining saloon, 81 of which are suspended over the tables in 3. lig electroliers banging from the ceiling. The remainder of the lam] are in small brackets and pendants so as to give light orer the sii scats. Abore tho saloon is the music-room, haring 17 lights rour the walls and orer the piano and organ. The smoking-room has al. 17 lamps. The remainder of the lamps are distributed about the shi 172 being in tho state rooms.

Basides the actual internal lighting of ships, electricity is used $f_{1}$ the bow and masthead lights. I understand that the Board. Trade docs not object to the use of tho electric light for ships' sir lights, but it requires oil lamps to be kept in reserve in case of failur With regard to masthead lightits, however, the Board discourages $t$ l use of electricity, partly on the ground of its liability to get out order in consequenco of vibration, and partly in consequence of $\mathrm{tl}$ brilliancy of tho light tending to interfero with shore lights, ar causo confusion. It is in fact not used for mastlicad lights, and on in a few cases for side lights, and it has not been thought necessas to issue any general instructions, though tho Board of Trade is no in communication with the Admiralty on the subject.

On this point thero bas been some discussion. The first liglits use were very mach brighter than the oil lamps which thes replaced, ar caused wistakes from their being taken for lighthonses, or frum tl distance of the slip using them being misjudged. There is, howeve great advantage in their use, from such uso secaring certain bnor ledye that the lights are all right. This is effected by the curre: passing to the lamp through an indicator on the bridge-in riew . the Officer of the watch!

The ordinary lights carried by ships-of-war when croizing in con pany are now in somo cases electric; and the electric light has bet ingeniously adapted to sionalling purposes.

One of the most complete arrangeinents got out by the well-knom firm of Sratter Lemonicr is as follows:-

Two groups, of fire glon-lamps each, aro suspended at a certa distance above each othrr, and the current is allowed to pass to ono more of them by a bes-board in the deck-house. In order to prevel inistakes, the signal is set before the current is allowed to pass to t1 required lamps, and this setting lights up a corresponding signal 
front of the operator, thus:-He wishes to show four lights, and four lamps in connection with a main switch. In doing so, he covers four little illuminated windows in front of him. Satisfic the appearance of this signal, he switches on the current from generator, confident that his signal will bo correct. A swit, merely a means of connecting or disconnecting one conductor another, as is also a firing key, which will be mentioned later on. the signalling may be done by hoisting the light and signalling the key; or again by dipping the light in a bucket. There is an application of the glow or incandescent lamp for the purpo: coaling or doing other work at night. In this case a group of a a dozen lamps are placed under a reflector which is triced up tc yard-arm, so as to light up the deck of the ship and the coal $\mathrm{w}$ or vessel alongside.

The glow-lamp is also useful for the diver, either in thick wat. at nighit; but special precautions haro to be taken to prerent globe being broken by pressure, and for this purpose it is enclese a second thick glass globe.

The electricity for the lamp is either derired from aboro $\pi$ through wircs kept carefully dry, and not tonching any metal, , is in some cases provided by a battery carried' bs the direr with lamp.

Messrs. Siebe and Gorman's lamp is of the latter kind. The ] is mounted in a parabolic reflector fixed to the side of the battery The battery will keep a constant light going for four to five hours

We now come to a different form of illumination, called the light. In this arrangement, a suitable carrent of electricit. allowed to pass through two carbon rods in contact, and then are slightly separated. The effect of this resistance or space it duccd into the circuit by separating, is to produce a very brill light, proceeding partly from the heated carbon rods, and partly $f$ a luminous are between them.

This light is very intense, too much so for many purposes. carbons burn away, so that some arrangement is necessary bringing them within the proper distance for the arc, and for placing them when entirely consumed.

This are light has been used for internal lighting, masthead lig and coaling lights, but the necessity of having somo apparatus feeding the carbons and other causes have forced it to give generally for these purposes, to the simpler glowe light.

For the senrch light, howerer, used for discorering torpedo-b approacling a ship, bombarding forts, and so on, the are light necessity, as great intensity is required. The search light is a like appliance, but had better be considered in connection with o uses of electric lighting. It is very useful for other pnrposes, suc. clearing the anchor at night, and such peaceful, or at any rate marlike, opurations. When the are is used for a scarch light, rays are all collected by means of lenses or mirrors, and projecte one beam, so as to get the strongest possible light.

The difference in power is immense between the glow and are lif 
in ordinary use at sea-tho glow-lamp representing only a few candles, seldorn more than 20-bat the arc as now used, about 25,000 , and a far.more intenso are light has been produced on shore.

$A$ boat can be discovered by it at a great distance.

In the West Indies, in a finc clear atmosphere, a building has been picked out clearly enough to be aimed at with a $g$ an, at a distance of two and a half miles, tho light ased being about 8,000 candles; but grent difficulty was experienced in keeping the beam on the object, as one could not see any distance unless standing away from tho light.

To obriate this, menns hare been devised for directing the beam by an observer at some distance from the lamp.

The search lights in general use are worked by a man who serews the carbons together as they burn away; this method, nndoubtedly crude, has been adopted chiefly for simplicity's sake, but it is high time that $\Omega$ suitable automatic lamp-that is, one which is self-feeding -should be introduced, and that the directing of the beam should be in the hands of the observer, although be is necessarily at some distance from the light.

The electric lights belonging to the ships hare been considerably used dnring the operations in Egypt; one was landed, generator and all, at Alesandria, and another at Suakim. The light was also much used at the latter place from on board, for discovering the approach of the enemy at night.

For signalling, the are light has been used for many years, the process being to flash the beam up in the sky in longs and shorts, using the Morse or some similar code.

To show what may be done in this way, it may be mentioned that during some of the electric light night exercises carricd out at Portsmouth from the Torpedo Scliool, the flashes of a light of about 20,000 candles were distinctly seen 31 miles from the ship, a low range of hills intervening; and $n$ similar light was reported to be seen still further when shown from a tower of tho Philadelphia Exhibition last year.

Again, somo ships being anchored in Ragusa and others in Graresa, signalled to each other in spite of the hills between, by flashing an arc light ap in the sky.

There is no difficulty in lighting op a building at 2 miles distance with a 20,000 candle light.

\section{Electric Communications.}

From signalling by the light at a distance, one passes naturally to other means of communication for which purpose electricity is more universally used than for any other.

Telegraphy in the nature of things is not in use much outside the ship, from tho difficulties of bringing in the wires with a ship swinging round her anchor; bat means have been devised for this useful object, which are especially applicnblo to light ships: telephones, and so on, can of course be used from a ship moored head and stern-in fact, light is sometimes supplied in this way.

TOL. $\operatorname{xxIx.}$ 
As regards electricity within tho ship herself, tho uses are ma Tho ordinary electric bell I need lardly drell upon, bat $t^{\prime}$ appliances most especinlly required in men-of-war aro first, a of knowing the speed of tho ressel at any time, and seconi telegraphing distances of the enemy ascertained in tho tops, Captain nnd gun batteries.

I am not awaro of any method, which is in rery gener: for obtaining the first result. But there are numcrous appr to it.

There are many instruments which give the speed of the $\mathrm{s}$ cngines for a grenter or less period of time, bat what is requir man-of-war is to know the speed at any instant.

Various electric logs do tho first, that is to say, the spaco over can be noted during any period, but tho speed at a giren $i$ is not shown. Even an instrament which showed at any insta specd of the engines rould bo a ascful improvement.

The principle of most electric logs is that the rerolutions fan periodically close a circuit. When this is done, a dial hand on ono dirision, usually a tenth of a mile. If, then, the elect be joined up to a recorder in the Captain's cabin, and another chart-house, and set at noon, both the Captain and tho Officer watch can see at ang time how far the ship has run sinco t] since the last time the instrument was looked at.

The difficultics of a joint which shall connect two conductol jet bo able to stand continually being revolred, appeurs to has dealt with in an original manner" in the "Dollond" log; the ciple is protected by patent, and is applicablo to tho attachm wires, for signalling to light ships or other ressels swinging their anchors.

This log will be sufficient to give an idea of theso instrument

The log ased in the Nary for recording tho distance passed $c$ a ship consists in a fan which is tored on the quarter of the sh which, as it revolres, shon's the number of miles passed over or plate attached. The disadrantago is that it has to be got on be order to see how much distance has been run.

Other logs which aro much uscd in mail steamers hare a fan $t$ but the recorder is on the taffrail, and is turned by the towing

The disadrantage is that the recorder can be in one plact and only one recorder can bo used.

It is claimed for the electric log that it is more trustrortb the taffrail log, and more usefal than either, in so far as one o recorders can be placed in ang required position. The adran obvious in nny ship in cruizing time; but in a ship of war in its raluo is enormously increased, for it is easy to place teleph. convection at any required point in the pilot towers, at tho bead directors, gan directors, and gum deck, for in firing a is necessary to bnow speed, and still more necessary when $f$ torpedo.

It indicates at once any mishap to the $\log$, by fouling or ce away. 
It sares the labour, loss of time, and error of registration involred in hanling in the log, which can remain in the wator, unless fouled, antil entering port.

Tho instantaneons registration of the distance run between two bearings enables narigators to calculato with accuracy their position in reference to a light, headland, or other fixed object.

The indicatnr can be re-set on board at any moment.

The addition of a small self-contained apparatus and a bell, which can be placed with tho indicator or in any other part of tho vessel, communicates by sound the regular rorking of the log, and enables the Offecr on watch to detect any irregularity and to take instantaneous bearings at giren distances, without referring to tho indicator or the log. .

A distanco indicator, derised by Lieutenanis Jackson and Anson of the "Vernon," has undergono already a trial in the "Excellent" and "Vernon," and has been favourably reported on, tho indicating hand is rotated in either direction, one step at a time. A spring brake prevents it from being thrown ont of adjustment by the concrission of firing heary guns. $A$ bell is fitted in the receirer which rings cach time a signal is completed. In the transmitter; a red disc shows when the circuit is completed, and the battery running, on circuit. The instruments are carefully protected from wet; they will work in any position, and aro entircls unaffected by damp and gun-fire; tro wires aro used with each circnit for connecting transmitfer with receiver. Tho commutator, howerer, is of dolicate construction, and the eprings on the armatures require careful adjustment for efficient working with low battery. power.

The great defect scems that there is no method of telling whether the two instruments, transmitter and receiver, are indicating the same signal, and if the battery be left on circuit for long it may fail to work the instrament.

The telephono is used from ship to shore, when ships are moored. In the "Vernon" ono was used to tho Captain's house and found most uscful. Through this telcphone, somo cight years ago, an Officer reconnized Professor. Bell's roice, which ho only knew from having heard him lecture in London, and he did not know the Professor was in Portsmouth.

The application of the telophono to diving is most valuable, and in my experience was perhaps the means of saving a man's life. He was just able to say, "Pnll mo up," and was fond quite insensible. It is strange to be capablo of hearing a man below water, a mile away, as well as if he was at your side. Some difficultics wero experieuced at first, but hare nor been completely ofercome. The same apparatus can bo adapted for use on shore.

'I'elegraphy for parties landed, thongh not a nsual equipment, is rerg useful, and $I$ have beon shipmates with a small feld telegraph consisting of a couple of sounders and reels of wire carricd by men.

For automatic indicators; electricity may be ased to indicate too great a rise of temperaturo in any compariment, to indicate if the ship is off her conrse-this is similar to an arrangement which will bo 3 в 2 
described for stecring a torpedo-or to indicato if the barometer beyond a certain point.

The application of electricity to testing the lightning condnctor ships is so simple that any trained seaman can obtain the resista without delicate instruments, with fair accuracy.

The propulsion and steering of boats by electricity is a sul which almost requires a separate paper to itself, and although si times used for war and sometimes for peace, the applianco is natu: similar whether a boat be carrying a torpedo or a policeman. $\&$ particulars of two boats which could carry either may be interest

The "Electricity," which was fitted by the Electrical Power Sto Company two jears ago, and which has run successfully $x$ hundreds of miles, is $\mathbf{2 5}$ feet long.

The "Australia," built by the order of Messrs. Stephens, Sr and Company, is of the same length; batteries or boxes of stored tricity in the boat, work a screw propeller. The cost of "Australia" is abont $180 l$. complete.

8 knots.

Each bont carries eight besides the coxsmain. Speed about

The advantages of electric propalsion are-

(1.) Entire absence of noise in the boat; in fact the only no that caused by the plash of the water against the boat's bows.

(2.) No smoke to interfere with the man steering.

(3.) No "flare up," which is practically impossible to preve very fast boats from the great draught up the funnel.

(4.) No heat, which tells so much on the stokers in a torpedo-

(5.) Not so large a number of men required as in a steam

The disadrantage of this form of motivo power is of cours necessity of having means to re-charge the cells again after use should this prove a successfal experiment, regular charging sta could easily be provided for a boat to go alongside and have her charged, as, for instance, night patrol boats could bo charged a side a jetty during the day for use at night. From the abse1 heat this form of motive power would be most valuable in ver climates.

The various appliances in a submarine cable ship are spec their character, and are hardly to be considered generally naval.

One of these is a cable creeper which has a push in angle c creep, so that if it catches a cable it rings a bell.

Now in the descriptions about to be giren, reference will be made to "testing." This testing is for the purpose of : whether the circuit, including the actual place of application, good order. The principal test is to see that the conducto appliance have a complete circuit. To do this, a small curr allowed to pass ronnd the circuit, too small to cause any appre heat, or to work the magnet, but large enough to affect an ind or ring a bell, which only require a small current, thus showing correct. Should there be any break in the circuit, the little $\mathrm{c}$ cannot pass, and so cannot ring the bell or affect the indicator. 
Tho current is supplied by a batters. A simple test battery and indicator will ensily show whether there is any breab or not in a coil of wire, or any electric circuit.

\section{Electricity Applied to War Purposcs.}

\section{Firing Guns.}

Wo will now consider tho applicntions of electricity to war purposes afloat, the first, the one considered most important, being firing guns.

The method of firing gans by elcctricity is simple.

The method of heating a wiro by passing electricity through it has already been explained.

To firo a gan, tho electric cnuent is allowed to pass through a piece of fino vire surrounded by powder, and placed in the rent of the gun. A firing key is used to allow the current to pass from the battery through the main wire to the little tubo of powder in the gan, and then back by tho return. If a vers small current be sent throngh the circuit, it will not heat the resistance; and if it be made to ring a bell in the pilot torrer, the Oficer in charge knows that the circuit is all right.

Some of the adrantages of firing guus by electricity nre as follows :-

When firing a broadsido of guns together, if electricity be used, it is fired much more simultancously than when using hand firing; and when firing singlo gans, the netion is more instantancous. This may be illustrated by $\Omega$ well-known machine. Any man trying to fire a gun at a certain time, or when certain objects are in a line, is only more or less successful in doing so-genemally less.

Another rery important adrantage of firing gans by electricity is that they can all bo fircd by an obserrer clear of the smoke of the gun-deck.

Again, the guns can bo fired from a bullet-proof pilot tower as the ship passes close by the enemy by any one person or the Captain himself, the crew lying down or bcing placed out of the was. This is especially advantageous in ships which have their guus on the upper deck exposed to machine-gan fire.

$A$ gain, there are cases where the object cannot bo seen from the gan, and electric firing provides an easy means of firing from aloft on the mast. Thus a ship in the Suez Canal fired at a train in motion, which was only risiblo from aloft, and bit it.

$\Lambda$ gain, the gan can bo aimed at a fixed floating plank, and be arranged so as to fire when tho plank is tonched. In fact, it acts as a spring gan agninst torpedo-boats.

Hilectric fring for a singlo gan was recommended by tho Chilian Offeers after the action in which the "Huascar" was taken, as the most likely to be effectire.

It must be allowed that there is the disadrantago with electricity of the chance of damago being done to the circuit, but this would be 
shown by the bell in the pilot tower. On the other hand, the adr tage is that its use simply alters a heavy pull off to:a light onefact it may be called a hair trigger.

Automatic Firing.-This is an arrangement for firing when ship is rolling; for instance, the gun is required to be fired when ship is upright, then tho circuit passes through a balance so arran: as only to connect the tro parts of the circuit, that from generator and that to the gun, when tho ship is upright; so $t$ directly the ship is in that position the gans aro fired.

The method is claimed to have been brought to great perfecti but is not so simple as it looks.

Electricity may be used to light. np the foresight at night. appliance for this purpose has been inrented by Captain $\mathrm{MCE}$. the well-known torpedoist. It consists of a little battery and glc lamp, which is screened except in the direction of the foresig The electricity has to pass through a similar arrangement to $t$. mentioned abore for automatic firing, so that the lamp is only when required.

It is capable of a much more practical application than automa firing, as a wide margin can be allowed to cover any crror from 1 rolling of the ship.

It secms specially useful for resisting night torpedo attacks.

And now for torpedoes, which como nert, at least, in importance Electricity is used for firing, propelling, and discharging torpedo

Just a word as to what torpedoes are. Thoy are movable st marine charges of explosires, used offensively.

The name "torpedo" is, oddly enough, derired from the clect fish, but I do not suppose he who first applied the word erer thoug that electricity would be so much used for firing theso charges.

\section{Firing Spar Torpedoes.}

The spar torpedo is the simplest form, consisting of a charge at $t$ end of a pole, which is put under an enemy's ship, and exploded.

For this form of torpedo electricity is now exclusively ased, a tho arrangement is usually as follows:- To the battery a firing key attached by a wire. This koy is joined to the main, so that pressing the loy tho circuit is complete through a fuze which similar in principle to the glow-lamp and which is in the torpec then back by the return to the battery-an exactly similar plan switching on lamps or firing guus.

There is also an arrangement by which the battery is joined to $t$ main direct, and the main goes to an automatic firing key in the he: of the torpedo, which acts on striking, then by the fuze and retu wiro back to the battery.

A combination of these methods is generally nsed, though pr bably a separation of them wonld be better. The spar torped thongh so simple, has at present tho greatest score-at least hnlfdozen ships-against travelling torpedocs, ono; and towing torpedo 
none. The cases occurred in the American Civil War, Rasso-'Tarkish, and Franco-Chinese wars.

$\Lambda \mathrm{s}$ in the case of the gan, a small current can bo sent through the fuze, and can ring a bell or work an indicator so as to show the circuit is correct.

\section{Firing Touring Torpedoes.}

The next torpedo, which to a great extent owed its want of farour in onr. Servico to bcing introduced withont electrical means of ignition, is the towing torpedo. This is, I beliove, always fired by contact with the cnemy's ship. When electricity is used, the circuit is from the battery to a contact picce in the torpedo, then to the faze, and back by the retarn to the battery.

Though we aro only concerned with electric firing, it shonld be explained that if ang other method of exploding a torpedo is used, it is, after once being made dangerous, equally so to friend or foe.

With all electrical appliances the removal of the rires from conncetion with the battery renders the torpedo as larmless as a box of explosires can be.

Batteries are the usual generators for firing torpedoes. Sonctimes, however, an exploder is used in which tho power is derircd from a man's muscular action.

\section{Firing, Fropelling, anl Steering Fish Torpedoes.}

Fish torpedoes claim our attention next, and thero are many binds of them; bat those with which electricity is used are ferr; in them the force dereloped in some part of the circuit is mado nso of to produce motion or put the rudder ono way or the other, or simply to fire.

When electricity is used for igniting the cliargo, all torpedocs are fircd in a similar way to one of those described for the spar and towing torpedoes, namely, at will or by contact.

1. 'There aro torpedoes which aro propelled from, and controlled from thcir base, as the Sims, named "controlled torpedoes."

2. Thero are torpedoes which contain their omn propelling power and aro uncontrolled and anconnected with the position from which they are started; for instance, Paulson's. They haro been called "ituto-mobile" torpedoes.

3. 'lhero are others which contain their own propelling power bat are connected with and controlled from their " base;" for instance, the Lay. They hare been called locomotive.

First, those driven by clectricity.

This is done either by electricity stored in accumnlators and put in' the torpedo, or through rires bringing tho electricity from the baso of operations.

In addition to fixed sabmarine mines, it las been considered riccessary, in some cases, for coast defenco to make uso of a controlled rootire torpedo, principally for attrcking ships which attempt to cleara passage through the sabmarine defences. 
. For this purpose a torpedo is required haring the followir perties :-

1. Iong range.

2. Handiness with the heln.

3. $\Lambda$ heary clarge, so as to be dangerous eren if stopped by a net defence.

4. Security from enemy's fire.

5. Power of passing floating obstructions.

6. Not casily scen or stopped by enemy.

7. A motive power always ready, and not dangerous.

8. Constant speed to end of ran.

9. Charge exploded at proper depth, for a charge on the sur comparatively harmless.

The torpedoes of Ericson, Lay, Howell, Whitehead, \&c., a considered by some good judges to fulfil theso requirements a pletely as that of Sims.

Common defects are, great complication, difficalty of prepari: keeping the torpedo ready, danger of explosion from the suk which drires it, great exposure to fire of enemy, want of speed, at the surface, \&c.

Tho Whitehead is considered unsuitable on account of its col tirely short rangc, because it cannot be steered, and for other $r$

The Sims torpedo is of the ordinary cigar or fish shape, driven by a current of electricity from a generator on shore, passes throngh a wire laid ont by the iorpedo as it goes, and $v$ screw propeller. The torpedo can be steered and fired by eler from the shore through the same cable. The torpedo is suspe few feet below the surface from a float which is just awash. are two different sizes-the larger carrying 2 miles of wire charge of 400 lbs. of dynamite.

The 2-mile torpedo is of copper so as not to rust, and is 28 feet long. The cable, which will just sink, is carried in a el to which the water is frecly admitted, so that the buoyancy torpedo is but littlo increased as the cable is paid out. 'i'he ch in the head. The wire chamber, which has a short tube unde leading aft, through which the wire is paid out, is in the centre, driving and stecing gear are in the after part of the torpedo stcering is dono by a separate current from a battery; the he] ouly be pat hard orer either way, and when released is bronghı ships by the action of the water.

The torpedo is suspended by strong steel frames about 4 feel a boat-shaped copper float of about the samo length as the th but whose bow is a few feet further aft. $\Lambda$ steel cutwater conne bows, and, as it slopes downward and forward from the float, $t$ force the torpedo under any boom or floating obstruction it ma with.

The float is built in water-tight compartnents, and fller some bnoyant substance, so that it is difficult to sink it. It the usual two upright rods-one with a white, the other a $r$ 
in the day time, and lamps at night. The rods are pirotted with counter-weights so as to gire and lie flat when passiug under an obstruction, and to riso again when clear. The speed is said to bo 12 knots.

The cable is of copper wire, and a small insulated wire in the heart of the main cable is used for steering.

The torpedo may of course easily be arranged to fire on contact if required. When it was tried by running at a spar, a spectator who was in a boat near did not seo it, although watching for it, until it was within 500 yards. The torpedo hit the spar in two successive trials within 4 feet of the point aimed at, and the marks on the spar were $1 \frac{1}{2}$ feet from each other.

The tloat has been riddled by bullets, and yet remained serriceable.

The great disadvantage of tho torpedo is its rant of speed. Some less clumsy method of maintaining it at its proper depth rould, doulutless, very much increase the speed.

There is no doubt an adrantage in controlled torpedoes which hare their motive power on shore, and thereforo have to carry less meight, but they can be only used from a special base.

Then those steered by electricity, though with somo other driving power.

The Paulson Torpedo.-In this fish torpedo the steering is electrical. The motive power is supplied by liquefied carbonic acid. This torpedo is automatically steered in a direct or straight conrse by means of a mariner's compass, the needle of which, on any deriation of the torpedo from its course, makes contact with ono or other of tro insulated studs situnted on either side of ono cnd of the needle, and completes an electric circuit; a lever then causes one propeller to rerolve at a quicker speed than tho other, and thas steer the torpedo and bring it back to its set course. Supposing the torpedo to be approacbing an ironclad, the mass of iron would canse the needle to make contact with one of the studs and the torpedo to be steered directly away from the ironclad, unless its path rere due north and south (magnetic), and, to prevent this, a needle of a second compass in the head of the torpedo is arranged to short circait the battery when attracted to one side or the other by the mass of iron.

The shell of the torpedo is made of compressed waterproof paper pulp, which is light and strong, has no effect on the compass needles, and is not casily affected itself.

In order to render the weapon more effective, it may bo controlled orer part of its course by means of an electric cable paid out from the torpedo as it progresses, and by which the current from a battery on shoro or on a ship is convejed to the two magnets so as to steer it on any desired course. When the whole of the cable is paid out, it is automatically detached, and tho self-steering apparatus comes into operation.

The Lay Torpedo. - This well-known weapon is another example of the application of electricity to steering a torpedo. It is driren by other means, bat lays out an insulated cable as it runs, and through this it is steered. It carries a very heary charge, and is usually run 
just on the surface. : It has not made sach rapid improrements the Whitehead in point of speed. The usual rods or lights are us for directing tho torpedo, and rery good practice is said to haro bi mado by it.

It has not been fortunate in war, for althongh thero was a rume that during tho late war in Sonth $A$ merica a Chilinn ressel was blo up by the Lay, I do not think that was the fact. There ras an atten to use it from a ship in the sane war, but that method conld har bo expected to bo saccessful.

\section{Discharging Fish Torpeloss.}

Tho sinplest form is to ring an electric gong as a signal for man standing by tho torpedo to start it, for it must bo underste that it is usually started from somewhere down below in a $s 1$ and therefore it is necessary to hare somebody up abore to dec when it is to be sent on its journey. $\Lambda_{n}$ improrement is, st 1 order "Ready," to full cock the discharging arrangement, tho sa morement connecting ap an clectric circnit which has only a bre on deck, and which, when traversed by a current, puts in motion machinery for discharging the torpedo.

Another and greater improvement is the torpedo tube, being fit. on tho inside with a cartridge, which, when ignited, projects torpedo.

T'he clnteb, which keeps the torpedo in the tubc, is arranged such a way that when withdrawn it makes electric contact with othernise insulated binding screw on the right of tho gun.

The torpedoes are armanged to be discharged by an Officer whe in the pilot-tower. In this case the firing key is in the pilot-tow betreen the battery and the place of npplication, and thero is a bri at the tube, so that there are tro breaks in the circuit; when $T$ nenrly at tho moment for firing, the word is passed down, when lever is pulled by hand, freeing the torpedo and making contact the gan. The torpedo is then fired by pressing the kes in tho ch: house.

Tho torpedo batterg, which mag be considered as a part of $n$ defe system, has been derised to defend any channel left in mines for passagc of friendly ships.

It consists of a submarine framowork, in which are fixed torp. tubes, each holding a fish torpedo.

The observing station, which may be distant and quite invisible an cnemy, is connected to the battery by a wire which gocs to electric faze.

A reight released by the explosion opens tho valro of the engi and frecs the torpedo from tho tube.

\section{Firing Subnarine Arines.}

Submarine mines are used by ships for the parpose of defend themselves, or anj harbour in which they may be lying, or for security of which they may be responsible, or for dropping beh 
them when retreating. They are charges of explosire, defensivo and fixed, fired under water.

The differenco between torpedos and mines is this:-If you want to be blown up, jou must go to the mine; but if jou don't rant to be blown up, you must stop the torpedo coming to jou.

The electrical methods of firing them are two: (1) firing at will; (2) firing by contact.

The observation method of firing at will may be briefly described as firing a submarine mine when the enemy is within rango of the effect of its cxplosion.

There are two difficulties in carrying ont this otherwise certain and simple plan. The enemy may not come within the range of the mine, and when he docs you may. not know he is there.

TVith tho first difficulty we have nothing now to do.

The second must be considered, as on it depeuds tho difference betreen the two electrical methods of firing mines.

The simplest, and in its nsual form, perhaps the worst plan, is by the method of cross bearings.

To go back to our circuit.

There is a generator in this case, a battery that is on shore. The main wire goes from the battery to No. 1 observer, from whom the mine bears, say south, that is, tho mine is directly sonth of him, then passes through his key; then goes to No. 2 observer, who has the mine, say, due cast of him, and who also has a key. The main then goes on to a fuze in the mine, and the retnrn takes the current back to tho batters.

A word about return wires : the resistance of a conductor depends, other things being equal, on its size; the earth being large docs not offer much resistance, and is often used as a return wire.

Now tho circuit is not complete unless No. 1 and No. 2 both press their keys. $\Lambda$ ship comes in. If ever she is south of No. 1 he presses his key. If ever she is east of No. 2 he presses his key; but the keys are never pressed together unless the slip is sonth of No. 1 and east of No. 2, that is, over the mine.

This system has lately been well described by an eye-witness, and I dare say you will understand his description better than mine.

"And now we are going to fire 'by obserration.' Thero is a mine of 18 lbs. of gun-cotton down yonder, 2 feet under water, and that barrel there is an enemy's ironclad steaming up the harbour. But she may also ran close by withont actually touching it. This continigency has been provided for by patting the mine in electrical connection with two observing stations. Yonder is ono perched up there some feet above the water. It is a wooden shed, constructed so as to be readily taken to pieces and put up agrain whererer it may bedesired. In actual service, it rould probably be half buried in the ground, and the front of it protected or rather concealed by a bank of turf. There are two of these obserring stations at different points of the compass, but both on the same electric circuit. The observers within them aro becping the object glasses of a couple of small telescopes following the ship there as it approaches the mine. 
"These telescopes aro so mounted, that until they both I exactly to the destructive area around the mine, the electric circui which it is to be automatically fired, is incomplete. The enemy $\mathrm{m}$ pass too far from the explosive underneath the water to be $n$ affected by it. - In that case there would be no use in firing. two telescopes looking from different points of riew, would no any instant converge their lines of sight at the mine, and $t$ would alwajs be a break in the circuit. The ship would go on way. She is working strnight for the mine, however. The get one telescope clicks into a sort of notch, and one break in the cir is repaired. Click goes the other telescope. The circuit is compl a tiny piece of platinum wiro is instantly raised to a white inside the mine, and up goes the ship, a volume of water leaping the air, some of it to the height of a charch steeple, bearing wit fragments of the unlucky tub that has done duty for the for ironclad, which, under similar conditions, would not bave gone u the air probably, but would have bad a hole knocked in her bol which would speedily hare sunk her.".

Other methods are the camera obscura; the plane table 1 telegraph from the second station; firing all the mines in the ne bourhood of the ship, so that one of them must hit her, and so on

The plano table is electrical. The telescope at one station mor ruler at the other, and when the observer finds this line and his over a mine, he fires.

"Observation" firing cannot be used at night or in a fog.

The other system, that of contact mines, is different. To : from the battery, the circuit goes to a contact ley in the tory and on to the fuze; when the torpedo is struck, then back by return.

A ship must actually hit this mine to set it off. The ship in blows herself up. She may pass close to anj number of mines, only a small charge is required.

The electrical disadvantage of this system is, that you cannot a small current through for testing, unless a boat or a friendly bumps the mine for you. This has led to complicated addit: The simplest of these is a rery high resistance which bridges oves break in the circuit, so you can always send a small testing cur round the circuit; but when the mine is struck, enough current go through the fuze to tire it.

The next addition was by means of a further appliance, so that action of a ship striking the mine could be imitated.

This has, been arranged by causing the magnetic effect of current passing through the high resistance to attract the other of the break in the circuit, so as to cut the high resistance out.

This is useful in two ways-it gives a far more trustworthy than a simple resistance, as it stands to reason that a delicate in: ment which works all right in the mine shows no serious dama done to it; and again, it is possible by this means to fire a mil well as by the contact of an enemy's ship.

There is another means of testing an electric contact mine- 
to have $a$ telephone in the mine with a ball on the diaphragm, so th: the motion of the mine in the water makes a noise in the telephone.

Electro-mechanical mines are those which carry their own batter inside. This saves wire, but if the mines aro picked up, is extravi gant in boats and men's lires.

In these mines menns must be used to keep the mino safe, whi being laid down. This is effected in the simplest form by keepin the wires apart, and joining them at a safe distance when the mine laid.

The dynamiters imitated a very common form which works 1 means of some chemical action. They put acid on blotting pape and got away while the acid was eating through it. This inine w: without a circuit-closer.

These electro-mechanical mines were used for the defence of Sunkit and were very successful, or seemed $s$, for after the explosion of os mine, the night attacks, to guard against which they wero laid, ceass for tiro months.

\section{The Torpedo Detector.}

This consists of a sinker, which is a heary case, and a bo designed to be carried in $\Omega$ boat, from which the cable hangs. It c: be so adjusted that no sound is heard in tho receirer. If, norr, $t$ bont is pulled slowly through the water and the sinker is thus draggi along the bottom, no noise will be heard in the receiver unless $t$ sinker comes into proximity with some mass of magnetic metal, sur ns a torpedo case. In this erent, however, a hamming noise will 1 heard in the receiver.

A slight and imperfect shetch has now been given of the applianc which como under the heading of this paper, and I think you w agree with me that no trouble, no care, no mones is wasted, which spent in tenching our men to make a proper use of electricity, whic as a servant, has been aptly compared, for ability and docility, to tl slave of the lamp, but which as a master, is always mysterious ar sometines terrible.

The Cratrysx: When Iieutenant Batien announced his intention of lecturing, "the application of electricity to naral purposes," I felt pretty sure that he wou not be able to exhanust his subject nor to exhaust his knowledge in one hour; a) I can tell you that as I hare been reading the lecture whilst he has delirezed that ho has been obliged to omit many rery interesting and important parts of $i$ there are also many experiments that he has been unable to giro owing to the $u$ fortunate aceident which has happened to his assistant operator. We shall be re glad to bear any remarks which anjone present may wish to make upon this rc interesting subject.

Admiral R. A. Scors: 1 remark was made by Admiral drthur when I was li here to the effect that recent discoreries haro been of great adrantage to we nations. I think they hare been of especial adrantage to our Colonies, which by $t$ use of torpedoes and with the aid of the English Squadron (which we in New Zeala al wass gladly welcome) will be rendered practically eafe. I think I may say, $S$ that you being present on occasions like this is of rers great adrantage, especia: for tho encouragement of young. Offcers, snd inducing them to como forward wi 


\section{$73 S$ ELECTRICITY AS APPLIED TO NAFAL PURPOSES.}

their opinions. I un sure all who haro heard this lecture must acknowled, the information it has courejed has bcen exceedingly raluable. I would $c$ lecturer to tell us whether the electric circuit cannot be completed by the return when the mine is laid out at a distance of two or three miles from the as a return cable for that distance rould be an expensire thing. It is eaid plate of metal-say about 2 feet squaro-is required on the slore side in $c$ tion with tho instrument. At any rato tho carth circuit answers for a rer siderable distance; but I should like to know whether it will do for great dis! Tre hare had to-day practical illustration of the many adrantages of the $c$ light. In passenger ressels it largely conduces to comfort, for it tends to kc atmosphero cool as compared with old systems of lighting. With respect: lceturer's obscrration as to laying down torpedoes to protect wide and narrow nels, I think there is no necessity to hare a rery largo number of mines eren fonner case, for the fact that mines are laid down srould be a deterrent to approaching. No man would risk his ressel (costing perhaps half a millios all his crew by coming within a mile of a mine. I think thercfore the mere dorn of mines would be a suflicient safeguard to most liarbours. With respect numerous automatic appliances and derices for various purposcs, I rcnture to that nothing can supersede the look-cut of the person. An automatio $\log j$ good, but it may go wroug - and I haro secn a great many automatic experi fail-but the obserration of the person does not fail, that is of one prope: etructed; for instance, an Officer knows how many rerolutions the engines ship are making, should aleo know the speed those rerolutions aro giring. beliere any person who obscrres carefully is able to calculato accurately the di - the rcsscl runs, \&c. I do not say that automatic appliances should not be usc they should alirass be supplemented by the elill of the person-in obserrir different points of departure as well as the distances run by the ship, and things of the eame kind. The lecturer did not state how near the elcetric $c$ might pass without any disadrantaro to the action of the compasses; but mention that in the "Kaikoura," in mhich I came home, Sir William Thor compass-the after one-ras not of tho slightest use; it $\mathrm{kepl}$ spinning roun the formard compisses (also Sir WW. Thomson's) were perfectly steady. The pass itself, although an admirablo one, jet under the circumstances of rib docs not appear to act correctly. As regards the ralue of torpedo-detectors $I_{\text {i }}$ beliere if the defenders are rigilant that the detectors can bo used. I thit defenders must be aslecp to allow their torpedoes to be found and lifted. Ir Zealand, for instance, wo hare whale and other boats, tugs, \&c., as rell as torpedo-bonts, that could always bo moring, and mould certainly prerent ac pedo mines from being taken up. The great thing ro require is to hare the de of our Colonics perfectly worked out in full accordanes with the opinions , Admiralty, because it is naral attack Colonials haro to guard against, and, ther any local defence to be efficient must neecssarily be supplemented by the Im Squadron.

Rear-Adniral the Hon. E. Frexsxice: We must all agrce with whe Chairman las said, that this lecture is one of tho greatest interest to the Scrrice, and also that it is a subject which it was ecarcely possible to deal w all satisfactorily to the lectures in the space of one hour. I s5mpatbized much with him on that point, and I dare say it is probable that most of the que which I now propose to ask would haro been anstrered if he could hare his lecturo a littlo longer. There aro only two or three points on which I pr to drell. One is the question of the electric light. Wo hare all heard the incardescent lights on board ship, and we all understand how extr. useful they must naturally be. But I do not wish to touch on that at pres am speaking now of the are lighit. I was cetremely glad to hear the lecturer that somo arrangements were likely to be made enabling the carbons to app each other automatically. All those who hare had to deal rith the clectric s light on board ship must be arare that ocensionally there is a splutter and a that is when the man in charge is obliged to rcarrange the carbons. It mouk rers great adrantage if that could be rectified. Then there is tho questi leceping the light bearing on an object as it passes. I hare recentIj fortunatel. 
the opportunits of condueting some experiments, in conjunction with the Offeer in charge of the "Dreadnought." In accordance with orders we receired, we tried the experiment of attacking the ship with torpedo-boats, and more especially tho question of discorering tho bonts and keeping them in sight by tho electric light. One of the greatest difficulties we experienced was after we had discorered the boat, in keeping the light upon it, and the reason for that has been mentioned by the lecturer. $I$ only wish to confirm what he has stated, that the man who is moring the projector is partially blinded by the light, and cannot keep it on the boat approncling, while we below or abore can seo perfectly well; the result is, we call out to him to moro the projector, and he perhaps pulls it a little too far, and so we lose the object. If, therefore, it could be so arranged that it could be directed by some person below the light we should find it of rery much greater use. As regards my experience in finding boats with the electric light, 1 must say I think, on the whole, the use of the light is rery raluable. We allowed the torpedo-boats to attack the ship while she was in darkness, and they had some difficulty naturally in finding us. At the same time, when we mished to put the clectric light on them there was considerable delay, by which I menn some half a minute's delay, and a question of half a minute at such a moment is rery raluable indeed. We found that the position of the light was of considerable importance, and that is a point to which attention has been directed by the Admiralty. I understand the Germans are in the habit of haring the light aloft, and we were directed to try some experiments in that was. We found that when the electric light was put into the main top, although unquestionably me had a greater range, Jet certainly the boat got under the raj of the light on sereral oceasions, and on the nhole, we were umanimously of the opinion that the nearer the light ras to the water the better. I sliould like to haro heard a little more about tho torpedo-boats in which the motive power is electricity. The lecturer, through want of timeperhaps the experiments hare not been sufficiently carried out-mas not able to giro us rery much detail as to that question. One great thing which we discorered, referring again to these small experiments I have mentioned, was that we could always hear the torpedo-boat before we could see her. The picket boats could hear the torpedo-boat a long time before it could be seen. That points to the absolute neccssity of haring quictness in the torpedo.boat, and shows the grcat adrantago of haring one which could be mored by clectricity, where we hare only just the serew moring and the slight spray made by the boat and nothing else. On some occasions we were able to see the sparks from the funnel. Of course with an clectric bont wo shall not haro the sparks from the funnel, therefore it will bo a distinct adrantage if wo can use the electric boat for torpedo purposes. No doubt there are some disadrantages. As regards speed, I understand that some boats hare been ordered and contracted for by the German Gorernment which allow of 12 knots speed. 12 knots is a considerable speed, and a speed which, as far as $I$ understand, has not hitherto been attained by electric boats : at tho same time, tre know perfectly well that our torpedo-boats are expected to go 21 lnots. I should like to know from the lecturer whether he is of opinion that any speed liko 20 knots may be expected to be obtained at some future day in these electric boats. Not only that, but it appears to me that there is some difficulty with reference to the number of rerolutions of the screw. I understand that electricity acting dircetly from tho motor will - drice the screw some 400 or 500 rerolutions, but that Jou hare the distinct disadrantage of not being able to regulate the rerolutions of the screw. In the electric boats which I hare seen you hare been unable to case the speed, but sou must go full speed ahead or astern. I would like to add one vord to what fell from the lecturer with reference to the necessity, or the rcry great adrantage, of being able to placo the electric light somerihere else besides on banrd the ship herself. We know that foreign Powers haro the electric light fitted in their steam launches, the Russian ships aro so fitted, and a great many foreign Powers have many ships so fitted. It could rery easily bo done, and I am giren to understand it has been contemplated by our Admiralty to place them in our bonts. I certainly think, in agreement with the lecturer, that if we could land them in certain places, or place them in picket boals, they would be a very great adrantage to us, and it would be rery poor fun for an enemy who was going to 
attack a ship to run ashore under the clectric light, and instend of attackin; ship, to get stranded. In attacks made by torpedo-boats, the Officers in the speat rery distinctly as to the extremely blinding effect of the light, and that the light is bept slining upon them it is absolutely impossible for them to jud the distance at all. The result was that they were liable to discharge their torp at something like 1,000 instead of 400 yards, which was the object ained o wish expressly, on my orn part, to thank Licutenant Batten for haring come to give us this lecture.

Admiral Bors: I should like to be permitted ta nsk one question with rega a rers important point, which I think has a great bearing on future torpedo fare, namely, the propulsion of boats by electricity. I would first bring to $~$ one conspicuous object, not mentioned by Admiral Fremantle, almajs present steamboats, which, from my experience, is the first thing discorered at niglit b clectric light, and that is the waste steam from the funnel. What I want the lecturer with regard to the electric propulsion is, whether anj improre has becn made sinec last year in the charging of the accumulators for the propt of the ressel. We were then told, I think in this theatre, that it took as lo charge the accumulators as the actual run of the boat; so that if sou ranted a to run six, eight, or ten hours it took actually that number of hours to chark accumulators, and conscquently tho boat was laid up for that time before the could be repeated, which is a rery material objection to the principle. I ask whether that objection still exists, and if there is ans prospect of its remored.

Admiral Gore Joxes : I think it is exccelingls entisfactors to us all to fini the torpedo question las made such little progress for a great number of year: is to our adrantage, no doubt, to do without them if we cav, and when $I$, Americs nothing gare me greater pleasure than to see a new torpedo tried, a find that it was an utter failure. It is only experienco that teaches us by degrees what an uncertain thing clectricity is, and how little we realls knom: it, and how littlo we hare been successful. I saw all the torpedoes in An tricd, especially the Lay torpedo; crerything was done that could possibly be to make it a success, and it certainly euded in failure. The torjedo which reapon of attack, we thought 80 much of at first, has nerer distinguished Jet; whether it will eventually do so or not I do not know, but $I$ hope not. the Ericson torpedo tricd, but it was a failure, and, in fact, I hare nol secn a torpedo that has not failed in most aftempts wlien it has been tried. I. reniark on another thing-the unexpected alwass happens. Commander Matt at the liead of the American torpedo school for a great many years, was sur, when lie got into the Chinese rirers to find that his circuit did not act; it ea a dead stop. IIe had tho usual metal plates and the water circuit, but he coul get it to act. Then he found oul it was the mud in the rirer that causer difference, and I recollect reading a rery interesting report on that. The thing perfectly successful in dunerica, and also in the late Frunco-Chincse $\mathrm{Wa}$ : the spar torpedo, and it is the only thing I beliere in still, because you ha: intelligence of the Offecrs to work it. With the epar torpedo sou know e: what you hare to do, and I hare ecen the most ndmirable experiments carrier I hare scen resscls of 200 tons blomn up-a resecl going 8 or 10 lnots, pi another ressel, putting her spar torpedo under it and blowing it up. I nert an experiment like that with anything else, but that was done orer and over. I $82 \pi$ the whole of the dmerican squadron in succession pass and use their torpedoes, in erery instance successfully, but $I$ nerer $s a$ w them successful anything clse. The fact is the spar torpedo is the only thing that brings the intelligence to bear, and the brarery of the men who hare to do the work. eay, notwitlustanding all this apparatus and the nunber of jcars we hare rorking at this subject, we hare no more certainty with regand to electricity prescnt moment than we bad sis or eight years ago. I will point out another which occurred when I ment out to America; thero was nothing that was so impressed on my mind by Captain Fisher, then the head of the torpedo esto ment, as the necessity of plicing the cable in such a was as to male the insu perfect-that a pin's point rould destroy the effect of the current if it $\pi$ 
water and was allowed to escapc. Well, the first thing I saw when I got orer to America was that they took up the ends of two parts of the cable, terjated tho wires together, and pitehod them into the water witbout ans insulation, and it acted as well as erer. I could not inake it out at all after all I had heard of the necessity of insulation. Howorer, I thought orer the circumstance, and I supposed that thes were using a superior form of dynamo-elect ric machino to ours, but this was not so, as tro of our machines wero superior in porer. I think wo certainly ought to push more abcad in our experiments than we do, and not allow any other nation to beat us with superior instruments to our own.

Lieutenant Cursmorx BATTEx : Admirsl Scott agked whether there might not bo a saring of wire by using the carth current for a mine at a distance. That is quite so, and it is alrass done in practice; in fact, on that drasing the conplete wirc circuit was merely put in to make it simpler. There has been a controversy, not in the matter of long distances but in the matter of short distanees, such as firing guns and using lights on a ship, as to whether it is adrisablo to use a wire or an carth circuit. Asthere ras not time to enter into all that controversy, I thought it better to hric complete rire circuits. In telegraphs and firing mince at a distance an earth return is always used to eare wire. With reference to the deflection of the compasses, I think I am right in asying if a wiro is 30 fect from a compass the compass is perfectly safe. The torpedo detector is not a machine for remoring the torpedo, but for sboring its prescnce. It is made on tho samo principlo as that little thing rhich was used to show the position of tho bullet when President Garfeld was shot. It is dragged along the bottom of the water, and there is an incrcased noiso from the telenhiono when it approacbes any unctal substance. Tho piching up of torpedocs is a thing outsido tho lecture. I ann afraid I was slightly inisunderstood about the automatic lamp. I did not esy that they were actually being introduced for search lights, but that I thought it was time they were introduecd. Automatio lamps aro used for rery long period; on shoro without requiring any attention, but the old nrgument in farour of using the hend lamp was that as the man had to be there to direct the ray of light he might as well attend to the lamp as well. What we want to get is that the man wbo directs tho light shall bo awaj from the lamp, and therefore ho cannot attend to the carbons, and it is no use putting another man up thero for that purpose.

Admiral Freyrstre : Are automatic arrangements being introduced ?

Licutenant Burtex: No, Sir, not into the Serrice: With respect to running boats by electricity, the bost I mentioned was a 25 feet boat, and they got 7 or 8 knots out of her. I do not think any cxperiment has been mado with a much larher boat. but no doubt with a Inrger bont a rery much larger number of cells could bo carricl, and a rery much higher specd obtained. Thero is no reason why a boat driven by electricity should not be slowed; it is rers simple to arrango that. As to the question of the charging of the accumulators detaining the bout for a long whilo in a useless condition, it is quite truo that it takes a long timo to clargo tho accumulators for driring a boat, but the sccumalators need not be fired in tho boat $\rightarrow$ it is only neccsinzy to haro two or moro sets of accumulators, and the bont can then come alongside and get in her charge of accumulators the samo as sho has to get in coal. No doubt it tules as long to charge the sct as it does to run tho bost. With regand to the insulation, I think there used to bo an armngement for firing an outrigger torpedo with a bare wire twisted in two diffezcnt lays of the rope, tho two ends being lept apart by a bit of stick. Of coursc, it. is rerj easy to fire with bare wire if jou hare a proper battery.

Admiral FREMASILE: They used ruther a weal balterg.

Admiral Gone Joses: It was better than the two others we had in use at the tinie.

Licutenant Bırrex : It is perfectly casy to firo a torpedo with a baro rire, but there is a certain amount of loss, and in order to fire it in the best waj, it is better to insulite the junction.

The Crasrirs: : I am sure I need not press jou to allow mo to return your thanks to Licutcnant Batten for his intcresting lecture and for tho opportunity he has giren us all of thinling orer this inportant subject. I will offer a rerg few remarks on what we hare beard from him. Ifter telling us of tho grent adrantages of illumi.

rOL. SXIX.

$8 \mathrm{c}$ 
nating a ship by clcetricity- Which are certainis fully as great as he has poi out-the safety from firc, and the perfect light giren-cspceially in the engine. and gun battcries, he pointed out that there ras a danger of the wholo of the 1 in the "Etruria," or any of thesc large ships, being extinguished by one accide the djamo or ongine. I think I am right in sajing that in the "Etruria" haro fire ects of drnaros nnd fre sets of engines, so that it would requiro a unusual conbination of accidents to put her in darlness. This safenourd multiplicity of dynamos is absolutely necessary when lighting a ship by elcetr Onc application of clectricits to naral purposc3 mhich is much каnted is a $\mathrm{ki}$ clectric log. In those fast Atlantic steamers that steam at the ratc of 18 , rnots, the only means they hare of ascertaining their speed is by lienring th log that we wers brought up with fifty sears ago. They use the old slip log, $t$ ing it erers two loours. They laro a hand reel for hauling it in; but that $i$ only log thes depend upon at the present moment. No doubt there is nothin: trueting to the skill of the Officers and inen using it, but I still beliere in meclis assistance and scientific assistance, and I should bo rers glad to sco scientific $b$ ledge applicd to gire us the speed of the ship at any momeni. It is a mat1 rers great importance. I cannot allow Admiral Scott's statement, that Sir $\mathrm{Wi}$ Thomson's compass will not stand ribration, to pass unnoticel. We haro tricd crers possible was, and $\pi c$ find that it will stand ribration better than anr cor we hare, excepting the ribration of a torpedo-boat, and in a torpelo-boat no i the liquid compas 3 is tho st cadiest compass jou can use. I do not wish to let forward to the world thiat Sir William Thomson's compass is not ateady unde ordinnry ribration of $B$ ghip. I think it is the best compas 3 me hare, and one rclied upon in all circumstances on board slip.

$\Delta$ dmiral Scots: There wero two or thrco of those compasses. It was the compass I spoko of where there was vibration. I did not speal of them gene only where there was great ribration.

Almiral Gone Joses : His sounding machine is not alluded to, but it i most perfect thing in the world.

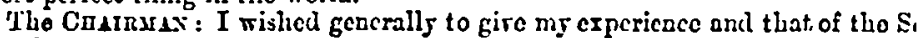
for the compass. There was one remark the lecturer made that I think we s] all tako to heart-Joung Officers, and I might eas old Officers as mell-whi this, that the boat with the electrio propulsion does not require skilled men to it; that a seaman who can stecr a boat, and do as he is told, nill mork that boal its machinery with perfect case. I hare no doubt that a great many OLiccrs, young and old, lasse an idea that it requires rers high scientific attainments tc trol the machinery for using electricity on board ship. No doubt the apparat this table rould frighten many, but the foct is, although it does require high tific attainments to elaborate and to apply electricity to all those operations of we hare heard to.daj, yet most of them are actusily manipulated and used wi any scientific knowledge at all. Three-fourth 3 of the work of the Scrric. alwajs been done and alwajs will be dono (electricity notwithstanding) $b$ worling, practical men of the Serrice, and thoy necd not be afraid that thes 1 unable to do their work as mell as it alrags has been dono because it require: a great amount of scientific bromledge to inrent and arrange tho apparntus used by clectrical means. I am afraid that some of them aro ncedlessly alarm the idea that a largo amount of scientific information and preliminary cducat required to work that apparatus; but sach is not the case; mucls no doubt is n by those who, like the lecturer, are capable of thoroughly understanding its in tion and of proposing means for improring it. I am sure you will authorizo return your thanks to Lieutenant Battca for bis intcresting lecture. I onls? had been dirided into two lectures instead of onc. 
NAMES OF MIEICBERS who joined the Institution between the ist January and the 30th June, 1885.

\section{LIFE IIEMIBERS.}

Newton, J. W. JI., Capt. R.A. Ingleficld, E. F., Lieut. R.N. Iotrc, F. MI., Lieut. R.A.

Stopford, F. G., Lieut. R.N. Wardrop, F. MI., Mrajor 3rd Drag. Gds. Marriott, R. C. S., It. D. of Corn. L.I. Besant, W. H., Lieut. Norf. Regt.
Arurray-Aynsley, W. F., Mrid. R.N.

Shrubb, H. A. B., MIid. R.N.

Heyworth, G. F., Mrajor late $3 r d \mathrm{Bn}$. Welsh Regt.

Bofle, A. G., Lieut. 4th Bn. Som. L.I. Collings, W. A., Major Berks Regt.

Mralcolm, II. II. L., Lieut. Cam. Highrs.

\section{ANNUAL SUBSCRIBERS.}

Tright, P. H., Lieut. R.N.

Ingles-Cliamberlaync, WV. C., Lieut. 2nd V.B. Glouc. Regt.

Taylor, E., IIajor 1st Herts R.V.

Walker, W. F.D., Lieut. R.N.

Napier, Hon. J. S., Mrajor Gord. Highrs.

Shenstone, F. S., Mrajor late Wore. Yco.

Gleadow, E. S., Lieut. 4th Drag. Gds.

Greenwood, J., Capt. 2nd MFiddr. Art. Vols.

Jolnston, J. G., Capt. Iate R.E.

Church, It. F., Lt.-Col. Com. Bra Mridds. R.V.

Taylor, St. J. S., Mrajor late 11th Kus.

Mrercer, A., Lieut. Edinb. Art. Miil.

Scott, W., Iieut. Edinb. Art. Mil.

Phillips, TV. C., IIaj.-Gen. late Mad.S.C.
Irall, F. II., Capt. R.A.

Prowse, G. T. T., Lt. D. of Corn. L.I. Hamilton, W. A. B., Mraj. E. Loth. Yco. MIcDonald, J., Lient. E. Loth. Feo. Head, II. S., Iicut. 4th Bn. Tore. Rt. MIaybery, H. O. A., Capt. Breek. R.V. Picrson, J. E., Capt. Royal Sussex Regt. Sandbach, W., Licut. Rojal Fus.

Douglas, R. G., Rear-Admiral.

Newcome, II. G., Major R.A.

De Jersey, T. G., Capt. R.A.

Gregorie, D. G., Lieut. Rogsl I. Regt.

Wodehouse, K. R. B., Major Wilts Rt.

IIudleston, E., Lieut. R.A.

Snell, W. C. If., Lieut. R.N.

Ruggles-Brise, H. G., Lieut. Gren. Gds. Pullen-Burr, H. B., Lt. 1st Herts R.T. 